
article, distributed under the terms of the Creative Commons Attribution licence (http://creativecommons. org/licenses/by/4.0/), which permits unrestricted re-use, distribution, and reproduction in any medium, provided the original work is properly cited.

\title{
UPWELLING OF PACIFIC INTERMEDIATE WATER IN THE SOUTH CHINA SEA REVEALED BY CORAL RADIOCARBON RECORD
}

\author{
Annette Bolton ${ }^{1,2} \cdot$ Nathalie F Goodkin ${ }^{1,2 *} \cdot$ Ellen R M Druffel ${ }^{3} \cdot$ Sheila Griffin $^{3} \bullet$ \\ Sujata A Murty ${ }^{1,2}$ \\ ${ }^{1}$ Earth Observatory of Singapore, Nanyang Technological University, 50 Nanyang Avenue, 639798 Singapore. \\ ${ }^{2}$ Asian School of the Environment, Nanyang Technological University, 50 Nanyang Avenue, 639798 Singapore. \\ ${ }^{3}$ Department of Earth System Science, University of California, Irvine, California 92697, USA.
}

\begin{abstract}
Annual radiocarbon from a massive Porites lutea coral collected from Hon Tre Island, Vietnam, South China Sea (SCS) was analyzed over a 100-yr-long period from AD 1900 to 1986. The pre-bomb results from $1900-1953$ show a steady $\Delta^{14} \mathrm{C}$ value of $-54.4 \pm 1.8 \%$ o $(n=60)$. These values are similar to coral records located in the central and southern SCS and from Indonesian waters, but are lower than those from Japan. Following the input of anthropogenic bomb ${ }^{14} \mathrm{C}$, our results show a sharp increase in $\Delta^{14} \mathrm{C}$ from 1960 , reaching a peak value of $155.3 \%$ in 1973 . The Hon Tre Island post-bomb $\Delta^{14} \mathrm{C}$ values are lower than those of other corals located in the SCS and Japan, but higher compared to those in the Indonesian Seas. This study infers a seasonal input of upwelled water depleted in ${ }^{14} \mathrm{C}$ from the deeper SCS basin that originates from the tropical Pacific via the Luzon Strait. The bifurcation of the North Equatorial Current feeds the surface and intermediate currents in the SCS and Makassar Strait region. However, unlike the Makassar site, this study's coral $\Delta{ }^{14} \mathrm{C}$ does not receive lower ${ }^{14} \mathrm{C}$ water from the South Pacific Equatorial Current. The Vietnam record therefore represents a unique oceanographic position, reflecting the seasonal influence of older, deeper SCS waters that upwell periodically in this area and have modified the surface waters locally in this region over the last $100 \mathrm{yr}$.
\end{abstract}

KEYWORDS: Porites, South China Sea, ${ }^{14} \mathrm{C}, \mathrm{Sr} / \mathrm{Ca}$, stable oxygen isotopes, Asian monsoon, post-bomb, pre-bomb.

\section{INTRODUCTION}

The calcium carbonate skeletons of marine calcifiers such as foraminifera, bivalves, and corals contain a useful array of geochemical proxies that have been used to improve our understanding of past climate, ocean circulation, and atmospheric to surface ocean processes (Smith et al. 1979; Beck et al. 1992; Gagan et al. 1998; Elderfield and Ganssen 2000; Schöne et al. 2004; Lynch-Stieglitz 2006). Coral carbonate reflects the $\Delta^{14} \mathrm{C}$ of surface seawater during the time and place of calcification because coral calcification uses dissolved inorganic carbon (DIC) from surrounding seawater, incorporating the radiogenic isotope ${ }^{14} \mathrm{C}$ proportionally (Goreau 1977; Erez 1978; Druffel and Suess 1983; Druffel 1987, 1997; Swart et al. 1996; McConnaughey et al. 1997; Reynaud-Vaganay et al. 1999).

Over the last $50 \mathrm{yr}$, the atmosphere and surface ocean $\Delta^{14} \mathrm{C}$ increased by nearly $100 \%$ and $20 \%$, respectively, due to nuclear weapons testing in the late 1950 s and early 1960 s. ${ }^{14} \mathrm{C}$ records in marine carbonates in surface waters lag those in the atmosphere, due to long equilibration times ( $\sim 10 \mathrm{yr})$ and regional oceanographic features caused by the global thermohaline circulation, local upwelling, stratification, and freshwater impact (Southon et al. 2002; Hua et al. 2004). A single oceanographic measurement is therefore not representative of the entire global ocean (Guilderson et al. 1998). The differences between $\Delta^{14} \mathrm{C}$ records of marine carbonates therefore allow the investigation of local and regional ocean circulation and thus can be used for testing and improving ocean circulation models (Reimer et al. 2013), adjustment of fossil marine sample ages, and allowing for the investigation of oceanographic processes in specific regions.

This article presents a new $\Delta{ }^{14} \mathrm{C}$ record, analyzed at annual resolution from a massive Porites lutea coral located at Hon Tre Island, Vietnam, in the South China Sea (SCS) to investigate the regional influence of atmospheric versus ocean circulation processes. We show the pre-bomb

*Corresponding author. Email: Nathalie@ntu.edu.sg. 


\section{A Bolton et al.}

and post-bomb record from AD 1900-1986, and compare to six records around the SCS region. Our Hon Tre Island post-bomb ${ }^{14} \mathrm{C}$ record shows values in between other coral records located in the SCS and Indonesian Seas and suggests influence of upwelled water from the Pacific North Equatorial Current (NEC).

\section{OCEANOGRAPHIC SETTING}

The SCS and surrounding region are marginal seas strongly influenced by the Asian monsoon, which is considered the most important factor for the formation and variation of the seasonal circulation (Hu et al. 2000). The primary exchange with the Pacific Ocean is in the northeast, via the Luzon Strait. This strait has the deepest sill, $\sim 1900 \mathrm{~m}$, allowing the surface waters of the NEC to enter the SCS periodically via the Kuroshio Intrusion (KI) (Figure 1). In general, the summer monsoon begins in May and ends in September, with the winter monsoon period starting in November and ending in February. Summer monsoon winds flow weakly from the southwest towards the northeast and vice versa in winter, leading to anticyclonic and cyclonic basin circulation,

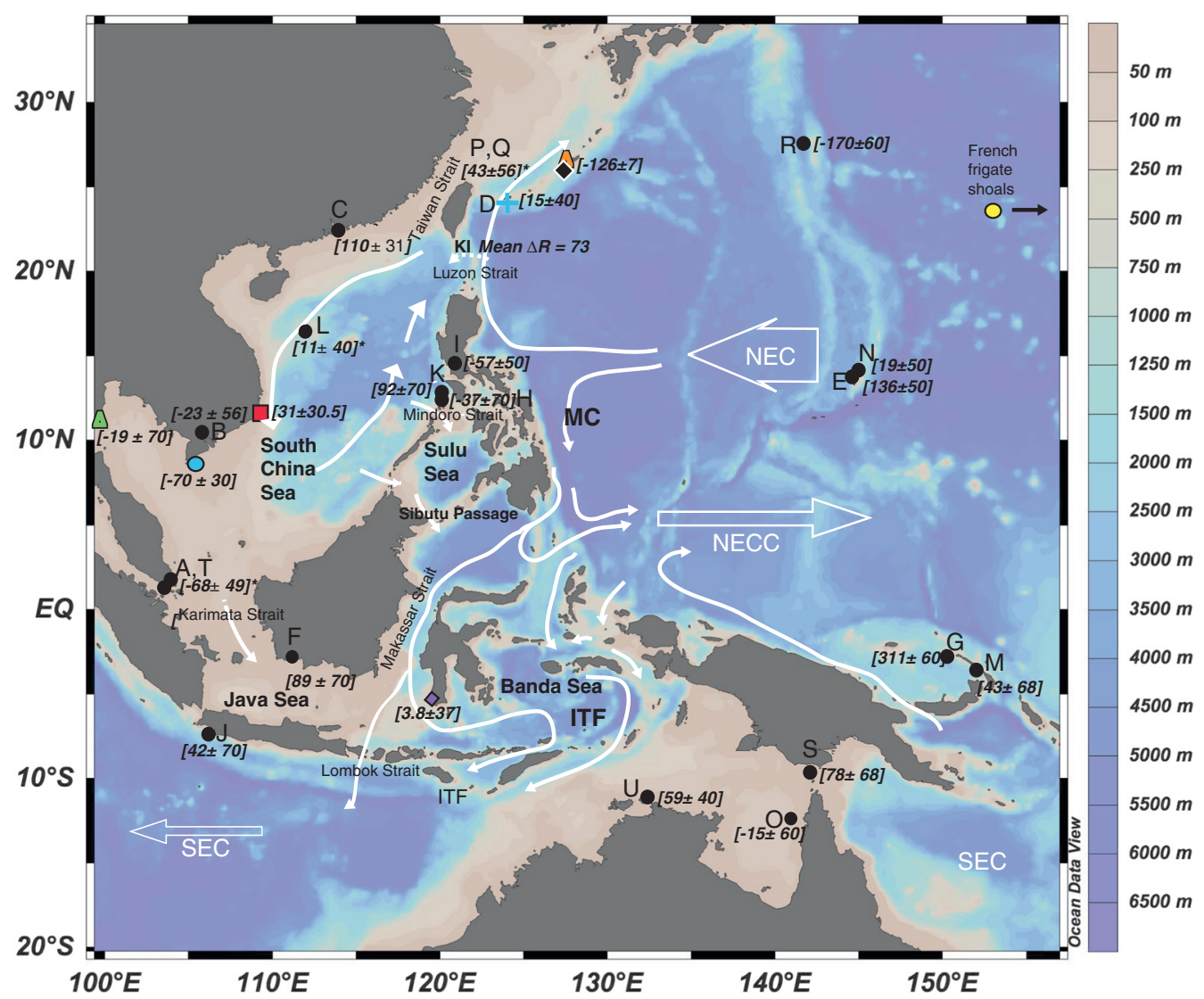

Figure 1 Bathymetric map (depth in meters on right axis) of the South China Sea and surrounding region. Mean annual circulation (white arrows) and marine reservoir corrections (black and colored symbols) are shown with errors where available $(\Delta \mathrm{R})$. The red square indicates this study's data $(y e a r=1950)$ to closely match the data from Vietnam reported in Dang et al. (2004) (blue circle). Other symbols indicate location of studies used for comparison (see Figure 2). Black circles indicate the locations of $\Delta \mathrm{R}$ values obtained from the marine reservoir correction database (http://calib.qub.ac.uk/marine/); see also Appendix 3. Asterisks indicate averaged records from the same location. NEC $=$ North Equatorial Current; NECC $=$ North Equatorial Counter Current; $\mathrm{SEC}=$ South Equatorial Current; ITF $=$ Indonesian Throughflow; KI $=$ Kuroshio Intrusion; $\mathrm{MC}=$ Mindoro Current. This figure was drawn using Ocean Data View (Schlitzer 2002). 
respectively, in which water flows along the east coasts of Indo-China and the western Philippines following the direction of the monsoon winds (Xu et al. 1982; Fang et al. 2005) (see Figure 1). The local bathymetry and stratification of the water column result in Ekman pumping and transport, which are important in the generation of summer upwelling offshore of the Vietnamese coast and of an offshore jet at $\sim 12^{\circ} \mathrm{N}$ further from the coast (Kuo et al. 2000; Dippner et al. 2007; Hein 2008; Chen et al. 2012; Wang et al. 2013; Zhang 2014). In the southern SCS, surface water seasonally circulates via the Karimata Strait while some is transported through the Sibutu Passage, returning to the Indian Ocean through the Makassar Strait via the Indonesian Throughflow (ITF) (Gordon et al. 2012).

\section{MATERIAL AND METHODS}

In March 2011, two Porites lutea corals were drilled from Hon Tre Island, Vietnam $\left(12^{\circ} 12^{\prime} 49.90^{\prime \prime} \mathrm{N}, 109^{\circ} 18^{\prime} 17.51^{\prime \prime} \mathrm{E}\right)$. Hon Tre Island sits on a shallow $\sim 100-\mathrm{m}$ coastal shelf and the corals are located at the northeastern tip of the island. The two corals, To Nhat (TN) and Bai Bans (BB), were sampled using an underwater hydraulic drill, producing 4.6-m-long and 2.4-mlong cores, respectively. Each core was sectioned and then cleaned ultrasonically in deionized water, dried, and then X-rayed to reveal annual density bands. The $\mathrm{Sr} / \mathrm{Ca}$ ratios from previous work confirm that darker bands (on an inverted X-ray) are formed during the winter and lighter bands during the summer (Bolton et al. 2014). A diamond-tipped drill bit mounted on a Dremel $^{\circledR}$ tool was used to drill annual bands from 1900 to 1986 from the longest coral (TN). In addition, one year (1969) was drilled at subannual resolution, by drilling parallel to growth axis in 1-mm increments to produce $\sim 7$ samples/yr. These subannually drilled bands were used to examine seasonal variability for that year. Subsamples of $\sim 200 \mu \mathrm{g}$ were analyzed for $\mathrm{Sr} / \mathrm{Ca}$ by completely dissolving in $2 \mathrm{~mL}$ of $5 \% \mathrm{HNO}_{3}$ and analyzing on an inductively coupled plasma optical emission spectrometer (ICP-OES) at the Marine Geochemistry Research Facility at Nanyang Technological University. Solution standards were used to correct for drift and matrix effects from varying Ca concentrations (Schrag 1999). The international coral standard JCp-1 was used as an internal standard, with a consensus $\mathrm{Sr} / \mathrm{Ca}$ value of $0.01932 \pm 0.0002 \mathrm{ppm}$ (Hathorne et al. 2013). Our measurements of JCp-1 yielded an average value of $0.01932 \pm 0.000068 \mathrm{ppm}(1 \sigma)$ (relative standard deviation $=0.36 \%, n=1620$ ).

For ${ }^{14} \mathrm{C}$ analysis, $7-8 \mathrm{mg}$ of coral powder were acidified with $85 \%$ phosphoric acid to convert the aragonite to $\mathrm{CO}_{2}$ gas. The resultant $\mathrm{CO}_{2}$ was reduced to graphite on iron powder using the zinc reduction method (Xu et al. 2007). The graphite was then analyzed for ${ }^{14} \mathrm{C}$ on an accelerator mass spectrometer (AMS) at the Keck Carbon Cycle AMS laboratory, using standard techniques (Southon et al. 2004; Santos et al. 2007). Sample backgrounds were subtracted, based on measurements of ${ }^{14} \mathrm{C}$-free calcite. We report ${ }^{14} \mathrm{C}$ measurements as agecorrected (or decay-corrected) $\Delta^{14} \mathrm{C}$ ( $\Delta$ term of Stuiver and Polach 1977). Total uncertainty of $2.4 \%$ was determined from the propagated error from averaged coral standards and duplicate samples measured. The data were not corrected for the Suess effect, the depletion of ${ }^{14} \mathrm{C}$ from fossil fuel emissions (Suess 1953).

\section{MARINE RESERVOIR AGE AND CORRECTIONS}

The ${ }^{14} \mathrm{C}$ marine reservoir age $(\mathrm{R})$ reflects the difference between the atmospheric modeled ${ }^{14} \mathrm{C}$ age and the conventional ${ }^{14} \mathrm{C}$ age of our coral samples, here expressed as the difference between the terrestrial calibration curve IntCal13 (Reimer et al. 2013) and our coral ${ }^{14} \mathrm{C}$ conventional age such that:

$$
\mathrm{R}={ }^{14} \mathrm{C}_{\text {coralage }}-{ }^{14} \mathrm{C}_{\text {INTCAL13age }}
$$


where ${ }^{14} \mathrm{C}_{\text {coralage }}$ is the age of the coral sample and ${ }^{14} \mathrm{C}_{\text {INTCAL13age }}$ is the age as estimated by the IntCal13 model (Reimer et al. 2013) for that same year. This value may also be different to the modeled R of the global surface oceans, e.g. Marine13 (Reimer et al. 2013), which is expressed as the regional marine reservoir correction or $\Delta \mathrm{R}$ (Stuiver and Braziunas 1993) such that

$$
\Delta \mathrm{R}={ }^{14} \mathrm{C}_{\text {coralage }}-{ }^{14} \mathrm{C}_{\text {MARINE13age }}
$$

where ${ }^{14} \mathrm{C}_{\text {coralage }}$ is the ${ }^{14} \mathrm{C}$ age of the coral for any particular year and ${ }^{14} \mathrm{C}_{\text {MARINE13age }}$ is the ${ }^{14} \mathrm{C}$ age as estimated by the Marine13 model (Reimer et al. 2013) for that same year. The $\mathrm{R}$ and $\Delta \mathrm{R}$ of our pre-bomb samples were compared to other corals in the SCS and surrounding region from previous studies.

\section{RESULTS AND DISCUSSION}

The Hon Tre Island pre-bomb (1900-1953) $\Delta{ }^{14} \mathrm{C}$ and associated $\mathrm{R}$ and $\Delta \mathrm{R}$ values are summarized in Appendix 1. The pre-bomb $\Delta^{14} \mathrm{C}$ values range from -60.8 to $-48.8 \%$ with an overall decrease of $-0.13 \%$ o yr, as estimated using a linear least-squares regression. Because the $\Delta{ }^{14} \mathrm{C}$ values are corrected for known age of formation, the decrease is assumed to be due to environmental changes including the Suess effect. Post-bomb annual (1954-1986) and seasonal (1969) $\Delta{ }^{14} \mathrm{C}$ values are reported in Appendix 2. Between 1954 and 1986, the Hon Tre Island annual $\Delta{ }^{14} \mathrm{C}$ has a range of $198.8 \%$, from a low of $-43.6 \%$ in 1953 to a high of $155.3 \%$ in 1973 $(n=29)$. The $\Delta^{14} \mathrm{C}$ values begin to rise in the early $1950 \mathrm{~s}$, and increase rapidly from $37.6 \%$ in 1962 to $74.5 \%$ in 1963 (Figure 2). Following the $\Delta^{14} \mathrm{C}$ high in 1973, which occurs approximately $10 \mathrm{yr}$ after the 1963 atmospheric bomb peak (Nydal 2000), $\Delta{ }^{14} \mathrm{C}$ values have been decreasing at a rate of $\sim 1.1 \%$ oyr. Using Equations 1 and 2, we calculated that our Hon Tre Island coral yields a $\mathrm{R}$ (from 1900 to 1950 ) of $342 \pm 19 \mathrm{yr}$ and $\Delta \mathrm{R}$ of $18 \pm 29 \mathrm{yr}$. The seasonal data in 1969 have a $\Delta^{14} \mathrm{C}$ range of $18 \pm 1.7 \%$ with the lowest values (138.4\%o) occurring during spring and the highest $(156.5 \%$ ) in the summer. The $\mathrm{Sr} / \mathrm{Ca}$ maxima (SST minima) are 9.195 $\mathrm{mmol} / \mathrm{mol}$ in late summer and $8.861 \mathrm{mmol} / \mathrm{mol}$ at the beginning of the year. The seasonal ${ }^{14} \mathrm{C}$ trend therefore increases towards the summer with a coeval shift in $\mathrm{Sr} / \mathrm{Ca}$ that reflects a change in SST from warmer to cooler temperatures (see Figure 2 inset).

\section{Pre-Bomb 1900-1953}

The SCS generally shows a distinct pre-bomb north to central/south variability in surface $\Delta^{14} \mathrm{C}$ owing, presumably, to the well-equilibrated source waters that enter from the western Pacific (Konishi et al. 1981) (Figure 1). Pacific (NEC) water enters the SCS via the KI, which occurs when the Kuroshio Current flowing from the tropical Pacific north past Japan intrudes into the SCS (Wu et al. 1998; Chu et al. 1999; Xie et al. 2003; Xue et al. 2004). The data in Figure 1 represent a compilation of pre-bomb $\Delta \mathrm{R}$ values from other carbonate fossil material collected from the SCS and surrounding areas (see Appendix 3). The data show that the $\triangle \mathrm{R}$ values within the central and southern SCS and those located south in the Indonesian Seas are equal (within $2 \sigma$ ). The R and the regional $\Delta \mathrm{R}$ for the SCS are estimated to be $281 \pm 84 \mathrm{yr}$ and $-23 \pm 52 \mathrm{yr}$, respectively (Southon et al. 2002; Dang et al. 2004) and are within $2 \sigma$ of the data from this study. Continuous pre-bomb records from the SCS and surrounding areas are scarce. However, Figure 2 shows available pre-bomb $\Delta{ }^{14} \mathrm{C}$ from the Andaman Sea $(-60.6 \pm 4 \%, n=1$, $\mathrm{AD} 1935$ ) and Makassar Strait (Langkai Island, $-55.0 \pm 3.5 \%$ o, $n=467$, AD 1900-1950), which share similar pre-bomb $\Delta{ }^{14} \mathrm{C}$ values with Hon Tre Island $(-54.3 \pm 1.9 \%, n=57$, AD 1900 1950). However, the annual trends in $\Delta^{14} \mathrm{C}$ are not consistent with this pattern. For example, there are some years when $\Delta^{14} \mathrm{C}$ in the Langkai Island (Makassar Strait) coral are higher 


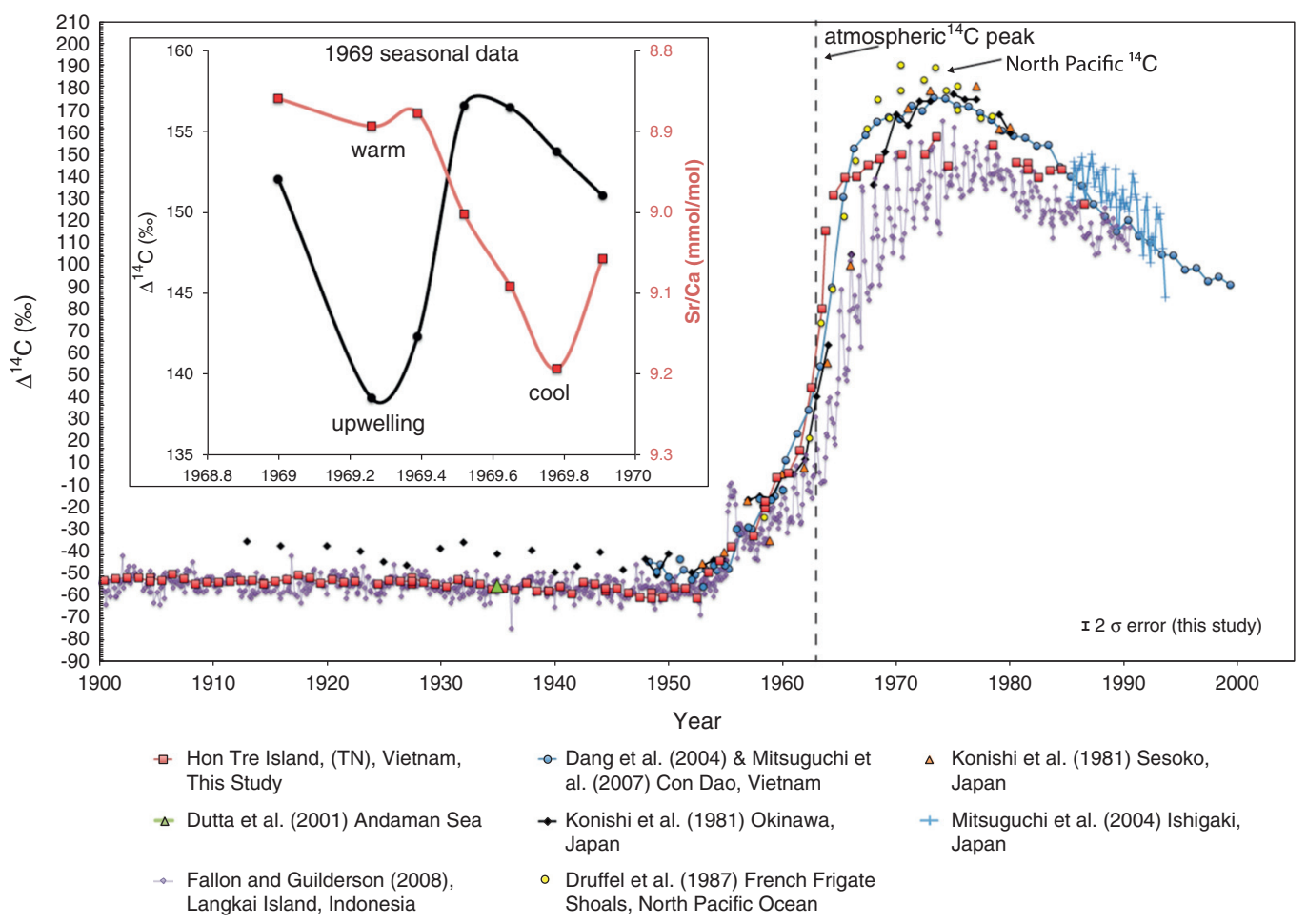

Figure 2 Annual coral $\Delta^{14} \mathrm{C}(\% \circ)$ data from this study versus those of other SCS and tropical coral records from the Pacific and Indonesian Oceans. Inset: Seasonal $\Delta^{14} \mathrm{C}$ (black filled circles) and $\mathrm{Sr} / \mathrm{Ca}$ (red filled squares) for 1969 to 1970.

(and vice versa) than our coral record. Some of this can be explained by the seasonality of the Langkai coral when compared to our annually resolved record; the former shows much higher variability. Both corals are also influenced by different monsoon systems. We discuss these in detail in the following sections.

\section{Post-Bomb Period 1954 to 1986}

Large differences appear when we compare the post-bomb $\Delta{ }^{14} \mathrm{C}$ data from corals in the SCS and those from the surrounding bodies of water. During this increased input of anthropogenic ${ }^{14} \mathrm{C}$, there are distinct differences in each of the coral records. Around the bomb peak, corals from Japan (i.e. NEC waters) are consistently higher in $\Delta^{14} \mathrm{C}$ (up to $179 \%$ in 1977 at Sesoko), with North Pacific corals from the French Frigate Shoals showing even higher values that peak earlier (189\% in 1970), whereas the Langkai Island coral's highest value is $163 \%$ o in 1974. Generally, these differences shown in Figure 2 agree well with the circulation of the SCS. Well-equilibrated water enters through the NEC via the KI, with the main throughflow moving surface water south along the Vietnam coast during the NE monsoon and flowing out through the Java Sea and into the ITF. In the Makassar Strait, the seasonal mixing of surface waters is complex but reflects the relative contribution of source waters from (1) the Indonesian Throughflow (ITF) originating from NEC and South Equatorial Current (SEC) surface and subsurface water, and (2) the South China Sea Throughflow, that enters the SCS from the Luzon Strait and exits it through the straits to the south (Qu et al. 2004, 2006). The relative contribution of these two source waters alternate during the SE and NW monsoon 


\section{A Bolton et al.}

(Gordon et al. 2012). Alternating mixing from tidal and Ekman pumping is extensive in the Indonesian Seas and changes the relative influence of NEC and SEC source waters that are transported through the Makassar Strait seasonally.

In the earlier part of the post-bomb Langkai Island record, a prominent but small peak in $\Delta^{14} \mathrm{C}$ is seen at around 1955, which was explained by Fallon and Guilderson (2008) as resulting from nuclear fallout from early bomb testing in the Marshall Islands in 1953. It is likely, however, that this peak is not detected in other records due to the proximity of the sites (i.e. lack of direct fallout) and/or smoothing from annual sampling. The Hon Tre Island post-bomb values rise rapidly from 37.6\% in 1962 to $74.5 \%$ in 1963 and peak at $155.3 \%$ in 1973 (Figure 2). The closest geographical $\Delta{ }^{14} \mathrm{C}$ record to our site is from Con Dao Island in southern Vietnam. $\Delta{ }^{14} \mathrm{C}$ at this location begins to increase sharply between 1963 and 1965 and reaches a peak of $173.8 \%$ in 1973. The relative difference in timing of these two records could be due (1) our site experiencing more rapid exchange of $\mathrm{CO}_{2}$ compared to the Con Dao record, overprinted by an upwelling signal, and/or (2) temporal changes in upwelling intensity, e.g. ENSO, that may also enhance or reduce gas exchange in particular years.

However, from 1966 onwards, the Con Dao Island record is consistently higher in $\Delta^{14} \mathrm{C}$ compared to our Vietnam record, almost matching the values in corals from Japan. Dang et al. (2004) and Mitsuguchi et al. $(2007,2008)$ have attributed this early rise and the enriched values to the shallow location of the coral on the Sunda shelf. Indeed, its location is isolated as it lies $\sim 300 \mathrm{~km}$ from the deeper SCS basin. The possible mechanisms for lower $\Delta{ }^{14} \mathrm{C}$ values at the Hon Tre Island coral site include (1) riverine input, (2) lateral advection, and (3) upwelling.

Freshwater rivers may contain lower $\Delta{ }^{14} \mathrm{C}$ owing to the dissolved inorganic carbon (DIC) from ancient carbonates, known as the freshwater effect (Philippsen 2013). We assume that riverine influence is negligible at our site due to the relatively small size of the nearest river (Cai) and the distance from this river to our coral site $(\sim 12 \mathrm{~km})$. However, we cannot discount small amounts of riverine input during periods of extreme rainfall (e.g. during La Niña events). Depending on the monsoon season, lateral surface water advection could lower (or increase) coral $\Delta^{14} \mathrm{C}$ values as evinced by the pre-bomb north to central/south variability in surface $\Delta^{14} \mathrm{C}$ (Figure 1).

Intrusion of ${ }^{14} \mathrm{C}$-depleted water that reaches Hon Tre Island (but not Con Dao Island) must therefore originate from the south, as NEC/KI waters indicate higher $\Delta{ }^{14} \mathrm{C}$ values (Konishi et al. 1981; Mitsuguchi et al. 2004). While northward flowing low- $\Delta{ }^{14} \mathrm{C}$ water could be present during the summer monsoon (Dale 1956; Wyrtki 1961; Guilderson et al. 2009), it cannot explain the higher $\Delta^{14} \mathrm{C}$ values found in the coral from Con Dao, which presumably would also be bathed in the same northward flowing water mass.

During the summer, there is a northeastward flow in the SCS and shallow coastal upwelling occurs at $\sim 12^{\circ} \mathrm{N}$ (Xu et al. 1982; Shaw and Chao 1994; Chao et al. 1996; Xie et al. 2003). This has been observed in numerous satellite, physical oceanographic, and model simulations (Pohlmann 1987; Kuo et al. 2000; Dippner et al. 2007; Barthel et al. 2009). ${ }^{14} \mathrm{C}$ measurements from intermediate and deep water in the SCS reported by Broecker et al. (1986) are significantly lower, ranging from $-106 \%$ at $420 \mathrm{~m}$ to $-204 \%$ at $4170 \mathrm{~m}$. The summer upwelling from Ekman transport is thought to be weak and limited to the upper $100 \mathrm{~m}$ of the water column (Dippner et al. 2007; Barthel et al. 2009). At the same time, wind stress is enhanced in the central SCS. The curl is positive in the northwestern SCS and negative in the southeast, with the strongest curl found off the coast of central Vietnam (Hein 2008). Dynamical upwelling, from the clockwise rotation of the northward undercurrent or stretching deformation-induced upwelling from this general circulation pattern in 
the SCS is thought to result in stronger upwelling (Dippner et al. 2007). This upwelled water is driven east and would therefore not reach the coral site at Con Dao Island.

The similarity of the post-bomb values in Langkai and the Hon Tre Island corals may initially suggest some connection between the upwelling rates and sources of the upwelled water (Figure 3). Both records have consistently lower $\Delta^{14} \mathrm{C}$ values compared to other corals located in the SCS with the Langkai Island coral having the lowest $\Delta^{14} \mathrm{C}$ values. The Langkai Island coral exhibits a clear seasonal signal with a range of 15 to 65\%o (Fallon and Guilderson 2008), whereas our seasonally resolved samples have a range of $18 \%$. This range is similar to coral $\Delta{ }^{14} \mathrm{C}$ values at Ishigaki Island, which exhibits a seasonal range of 15 to $40 \%$ (Mitsuguchi et al. 2004). The lowest $\Delta^{14} \mathrm{C}$ values at Langkai and Ishigaki Islands are observed during

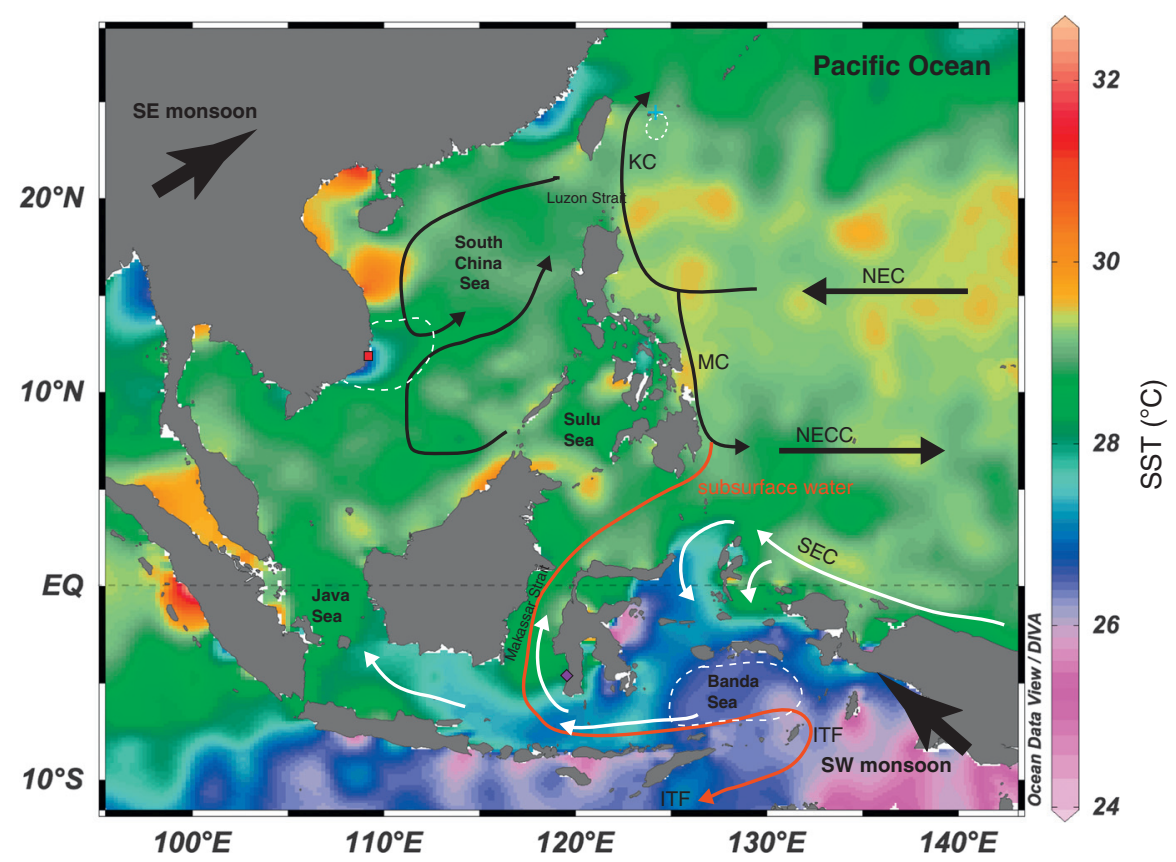

Figure 3 Ocean circulation and average sea surface temperature for August (1955-2012) in the South China Sea and adjacent seas. The red square indicates this study's site, and the purple filled diamonds indicate the coral location of Fallon and Guilderson (2008) at Langkai Island and the blue cross Ishigaki Island (Mitsuguchi et al. 2004). Black arrows illustrate the main surface circulation of the SCS including the basin-scale cyclonic summer gyre (modified from Wang and Li 2009) and source waters from the Pacific Ocean (North Equatorial Current). White arrows indicate the surface ocean currents originating from the South Equatorial Current and red arrows indicate subsurface currents for the same months (modified from Fallon and Guilderson 2008). In general, during May-September, the monsoon winds in the Northern Hemisphere move from the southeast towards the northeast leading to anticyclonic basin-wide circulation in the northern half of the SCS. Ekman pumping and transport generate upwelling offshore of the Vietnamese coast (white dotted area) with the northeasterly flow diverting offshore at $\sim 12^{\circ} \mathrm{N}$ further from the coast (Kuo et al. 2000; Dippner et al. 2007; Hein 2008; Chen et al. 2012; Wang et al. 2013; Zhang et al. 2014). During the same months in the Southern Hemisphere, in the region of the Indonesian Seas, the winds blow from the southwest towards the northeast. At the same time, the Banda Sea experiences intense vertical mixing, leading to lower surface seawater ${ }^{14} \mathrm{C}$ content (Ffield and Gordon 1996; Cresswell and Luick 2001). NEC $=$ North Equatorial Current; NECC $=$ North Equatorial Counter Current; SEC $=$ South Equatorial Current; ITF = Indonesian Throughflow; $\mathrm{KC}=$ Kuroshio Current; $\mathrm{MC}=$ Mindoro Current. This figure was drawn using Ocean Data View (Schlitzer 2002) using SST data from the World Ocean Atlas 2013 (Locarnini et al. 2013). 


\section{A Bolton et al.}

the boreal summer/austral winter (August) around the same time that upwelling can occur at our coral site. If upwelling is the main reason for our lower $\Delta^{14} \mathrm{C}$ values, then we also expect there to be similar seasonal variation, lowest during the boreal $\mathrm{SW}$ summer monsoon and highest during the boreal NE winter monsoon. Although we only have data for one subannually resolved year, the $\Delta^{14} \mathrm{C}$ values show a distinct range that suggests upwelling during this year is occurring in the spring, with $\mathrm{Sr} / \mathrm{Ca}$ data indicating warm, but not maximum, sea surface temperatures. The $\mathrm{Sr} / \mathrm{Ca}$ is the lowest towards late autumn, which matches a sharp rise in $\Delta^{14} \mathrm{C}$ that slowly decreases towards the winter. This observation in our record is intriguing and requires further investigation. However, prima facie, the seasonality observed in our record is similarly in phase with the Langkai and Ishigaki Islands seasonal cycle, although our SST proxy does not perfectly match up with the $\Delta{ }^{14} \mathrm{C}$, an observation also noted in the Ishigaki study. Mitsuguchi et al. (2004) hypothesized that the seasonality of their $\Delta^{14} \mathrm{C}$ values was related to the monsoon-induced local upwelling. Higher North Pacific $\Delta^{14} \mathrm{C}$ values are observed here, with the SSW-S monsoon during spring and summer inducing Ekman transport. The offshore transport of surface water leads to coastal upwelling of ${ }^{14} \mathrm{C}$-depleted subsurface water.

Fallon and Guilderson (2008) attributed the lower $\Delta^{14} \mathrm{C}$ values at Langkai Island to extensive upwelling occurring in the Banda Sea (East Indonesian Seas). The Banda Sea water has inputs from the South Pacific Equatorial Water, which is lower in $\Delta^{14} \mathrm{C}$ than that of NEC water. This would explain the overall lower $\Delta^{14} \mathrm{C}$ values compared to Hon Tre Island record. Although more data are required, our post-bomb $\Delta^{14} \mathrm{C}$ record also hints at seasonal input of upwelled water. This upwelled water appears to be a consistent feature that mixes significantly low $\Delta^{14} \mathrm{C}$ water from below the mixed layer with the surface waters in the region of Hon Tre Island. The source of this upwelled water is from the deeper SCS basin that originates from intermediate water fed from the Pacific via the Luzon Strait. The same NEC waters also influence the corals in the Makassar Strait and off the southern Sumatran coast, but consist of a mixture of both NEC and SEC water, the latter of which is more depleted in ${ }^{14} \mathrm{C}$.

\section{CONCLUSIONS}

We present a new annual $\Delta^{14} \mathrm{C}$ record for the years 1900 to 1986 and one subannual record of $\Delta{ }^{14} \mathrm{C}$ and $\mathrm{Sr} / \mathrm{Ca}$ (1969), from Hon Tre Island, Vietnam, extending the southern SCS $\Delta{ }^{14} \mathrm{C}$ record. Our pre-bomb coral $\Delta^{14} \mathrm{C}$ record, along with other pre-bomb records from the southern part of the SCS, show a low marine reservoir effect, and are significantly lower than those from Japan. Following the input of bomb ${ }^{14} \mathrm{C}$, our coral showed $\Delta{ }^{14} \mathrm{C}$ values that lie in between those from corals bathed in NEC waters and those in the path of the ITF in the Makassar Strait. The data suggest that upwelling at both sites is controlled by different mechanisms under a boreal summer monsoon regime - the combination of Ekman transport and the basin-wide gyre system in the SCS affect upwelling rates at Hon Tre Island - whereas the strength of the Southern Hemisphere SE monsoon affects upwelling rates in the Banda Sea and subsequent advection of water in corals in the ITF. The Langkai coral record represents the relative mixing rates between NEC and SEC intermediate source waters entering the Indonesian Seas; the lower $\Delta^{14} \mathrm{C}$ values in the Langkai record reflect more seasonal influence of modified, upwelled NEC and SEC water. Our Hon Tre Island record represents only seasonal NEC sourced intermediate SCS waters that enter through the Luzon Strait and are periodically upwelled at our study site.

\section{ACKNOWLEDGMENTS}

We thank two anonymous reviewers for their helpful comments. We also thank to K Hughen and J Ossolinski from Woods Hole Oceanographic Institution and the Nha Trang Institute of Oceanography for assistance with coral identification and collection. We also thank $\mathrm{Ng}$ 
Sin-Hwee for her assistance in subsampling the coral. This study was funded by the National Research Foundation Singapore under its Singapore NRF Fellowship scheme awarded to N F Goodkin (National Research Fellow Award No. NRF-RF2012-03), as administered by the Earth Observatory of Singapore and the Singapore Ministry of Education under the Research Centres of Excellence initiative.

\section{REFERENCES}

Athens JS. 1986. Archaeological investigations at Tarague Beach, Guam. Report prepared for Base Civil Engineering, Andersen Air Force Base. Honolulu: International Archaeological Research Institute. $113 \mathrm{p}$.

Barthel K, Rosland R, Thai NC. 2009. Modelling the circulation on the continental shelf of the province Khanh Hoa in Vietnam. Journal of Marine Systems 77(1-2):89-113.

Beck JW, Edwards RL, Ito E, Taylor FW, Recy J, Rougerie F, Joannot P, Henin C. 1992. Seasurface temperature from coral skeletal strontium/ calcium ratios. Science 257(5070):644-7.

Bolton A, Goodkin NF, Hughen K, Ostermann DR, Vo ST, Phan HK. 2014. Paired Porites coral Sr/Ca and $\delta^{18} \mathrm{O}$ from the western South China Sea: proxy calibration of sea surface temperature and precipitation. Palaeogeography, Palaeoclimatology, Palaeoecology 410:233-43.

Broecker WS, Patzert WC, Toggweiler JR, Stuiver M. 1986. Hydrography, chemistry, and radioisotopes in the Southeast Asian Basins. Journal of Geophysical Research 91(C12):14,345-54.

Chao S-Y, Shaw P-T, Wu SY. 1996. Deep water ventilation in the South China Sea. Deep-Sea Research I 43(4):445-66.

Chen C, Lai Z, Beardsley RC, Xu Q, Lin H, Viet NT. 2012. Current separation and upwelling over the southeast shelf of Vietnam in the South China Sea. Journal of Geophysical Research: Oceans 117(C3): $\mathrm{C} 03033$.

Chu PC, Edmons NL, Fan C. 1999. Dynamical mechanisms for the South China Sea seasonal circulation and thermohaline variabilities. Journal of Physical Oceanography 29(11):2971-89.

Cresswell GR, Luick JL. 2001. Current measurements in the Halmahera Sea. Journal of Geophysical Research 106(C7):13,945-51.

Dale, WL. 1956. Wind and drift currents in the South China Sea. The Malaysian Journal of Tropical Geography 8:1-31.

Dang PX, Mitsuguchi T, Kitagawa H, Shibata Y, Kobayashi T. 2004. Marine reservoir correction in the south of Vietnam estimated from an annually-banded coral. Radiocarbon 46(2): 657-60.

Dippner J, Nguyen K, Hein H, Ohde T, Loick N. 2007. Monsoon-induced upwelling off the Vietnamese coast. Ocean Dynamics 57(1):46-62.

Druffel ERM. 1987. Bomb radiocarbon in the Pacific: annual and seasonal timescale variations. Journal of Marine Research 45(3):667-98.
Druffel ERM. 1997. Geochemistry of corals: proxies of past ocean chemistry, ocean circulation, and climate. Proceedings of the National Academy of Sciences of the USA 94(16):8354-61.

Druffel EM, Suess HE. 1983. On the radiocarbon record in banded corals: exchange parameters and net transport of ${ }^{14} \mathrm{CO}_{2}$ between atmosphere and surface ocean. Journal of Geophysical Research: Oceans 88(C2):1271-80.

Dutta K, Bhushan R, Somayajulu BLK. 2001. $\Delta$ R correction values for the northern Indian Ocean. Radiocarbon 43(2A):483-8.

Elderfield H, Ganssen G. 2000. Past temperature and $\delta^{18} \mathrm{O}$ of surface ocean waters inferred from foraminiferal $\mathrm{Mg} / \mathrm{Ca}$ ratios. Nature 405(6785): $442-5$.

Erez J. 1978. Vital effect on stable-isotope composition seen in foraminifera and coral skeletons. Nature 273(5659):199-202.

Fallon SJ, Guilderson TP. 2008. Surface water processes in the Indonesian throughflow as documented by a high-resolution coral $\Delta{ }^{14} \mathrm{C}$ record. Journal of Geophysical Research: Oceans 113(C9): C09001.

Fang G, Dwi S, Indroyono S, Quan'an Z, Qiao F, Wei Z. 2005. A note on the South China Sea shallow interocean circulation. Advances in Atmospheric Sciences 22(6):946-54.

Ffield A, Gordon AL. 1996. Tidal mixing signatures in the Indonesian Seas. Journal of Physical Oceanography 26(9):1924-37.

Gagan MK, Ayliffe LK, Hopley D, Cali JA, Mortimer GE, Chappell J, McCulloch MT, Head MJ. 1998. Temperature and surface-ocean water balance of the mid-Holocene tropical Western Pacific. Science 279(5353):1014-17.

Gillespie R, Polach HA. 1979. The suitability of marine shells for radiocarbon dating of Australian prehistory. In: Berger R, Suess HE, editors. Radiocarbon Dating, $9^{\text {th }}$ International ${ }^{14} \mathrm{C}$ Conference, Proceedings. Berkeley: University of California Press. p 404-21.

Goodkin NF, Switzer AD, McCorry D, Angeline N, Yang T. 2011. Coral communities of Hong Kong: long-lived corals in a marginal reef environment. Marine Ecology Progress Series 426:185-96.

Gordon AL, Huber BA, Metzger EJ, Susanto RD, Hurlburt HE, Adi TR. 2012. South China Sea throughflow impact on the Indonesian throughflow. Geophysical Research Letters 39(11):L11602.

Goreau TJ. 1977. Coral skeletal chemistry: physiological and environmental regulation of stable 
isotopes and trace metals in Montastrea annularis. Proceedings of the Royal Society of London B 196:291-315.

Guilderson TP, Schrag DP, Kashgarian M, Southon J. 1998. Radiocarbon variability in the western equatorial Pacific inferred from a high-resolution coral record from Nauru Island. Journal of Geophysical Research: Oceans 103(C11):24,641-50.

Guilderson TP, Fallon S, Moore MD, Schrag DP, Charles CD. 2009. Seasonally resolved surface water $\Delta^{14} \mathrm{C}$ variability in the Lombok Strait: a coralline perspective. Journal of Geophysical Research 114:C07029.

Hathorne EC, Gagnon A, Felis T, Adkins J, Asami R, Boer W, Caillon N, Case D, Cobb KM, Douville E, deMenocal P, Eisenhauer A, GarbeSchönberg D, Geibert W, Goldstein S, Hughen K, Inoue M, Kawahata H, Kölling M, Cornec FL, Linsley BK, McGregor HV, Montagna P, Nurhati IS, Quinn TM, Raddatz J, Rebaubier H, Robinson L, Sadekov A, Sherrell R, Sinclair D, Tudhope AW, Wei G, Wong $\mathrm{H}$, Wu HC, You C-F. 2013. Interlaboratory study for coral $\mathrm{Sr} / \mathrm{Ca}$ and other element/Ca ratio measurements. Geochemistry, Geophysics, Geosystems 14(9): 3730-50.

Hein H. 2008. Vietnam upwelling - analysis of the upwelling and related processes in the coastal area off South Vietnam [PhD dissertation]. Hamburg: Universität Hamburg. 163 p.

Hideshima S, Matsumoto E, Abe O, Kitagaawa $\mathrm{H}$. 2001. Northwest Pacific marine reservoir correction estimated from annually banded coral from Ishigaki Island, Southern Japan. Radiocarbon 43(2A):473-6.

Hu J, Kawamura H, Hong H, Qi Y. 2000. A review on the currents in the South China Sea: seasonal circulation, South China Sea Warm Current and Kuroshio Intrusion. Journal of Oceanography 56(6):607-24.

Hua Q, Woodroffe CD, Barbetti M, Smithers SG, Zoppi U. 2004. Marine reservoir correction for the Cocos (Keeling) Islands, Indian Ocean. Radiocarbon 46(2):603-10.

Konishi KJ, Tanaka T, Sakanoue MM. 1981. Secular variation of radiocarbon concentration in seawater: a sclerochronological approach. In: Gomez ED, editor. Proceedings of the Fourth International Coral Reef Symposium. Volume 1. Manila: Marine Sciences Center, University of the Philippines. p 181-5.

Kuo N-J, Zheng Q, Ho C-R. 2000. Satellite observation of upwelling along the western coast of the South China Sea. Remote Sensing of Environment 74(3):463-70.

Locarnini RA, Mishonov AV, Antonov JI, Boyer TP, Garcia HE, Baranov OK, Zweng MM, Paver CR, Reagan JR, Johnson DR, Hamilton M, Seidov D. 2013. World Ocean Atlas 2013, Volume 1: Temperature. Levitus S, editor; Mishonov A, technical editor. NOAA Atlas NESDIS 73. p 40.
Lynch-Stieglitz J. 2006. Tracers of past ocean circulation. In: Turkekian KK, Holland HD, editors. Treatise on Geochemistry. Volume 6: The Oceans and Marine Geochemistry. Oxford: Elsevier. p 435-51.

McConnaughey TA, Burdett J, Whelan JF, Paull CK. 1997. Carbon isotopes in biological carbonates: respiration and photosynthesis. Geochimica et Cosmochimica Acta 61(3):611-22.

Mitsuguchi T, Kitagawa H, Matsumoto E, Shibata Y, Yoneda M, Kobayashi T, Uchida T, Ahagon N. 2004. High-resolution ${ }^{14} \mathrm{C}$ analyses of annuallybanded coral skeletons from Ishigaki Island, Japan: implications for oceanography. Nuclear Instruments and Methods in Physics Research B 223-224:455-9.

Mitsuguchi T, Dang P, Kitagawa H, Yoneda M, Shibata Y. 2007. Tropical South China Sea surface ${ }^{14} \mathrm{C}$ record in an annually-banded coral. Radiocarbon 49(2):905-14.

Mitsuguchi T, Dang PX, Kitagawa H, Uchida T, Shibata Y. 2008. Coral $\mathrm{Sr} / \mathrm{Ca}$ and $\mathrm{Mg} / \mathrm{Ca}$ records in Con Dao Island off the Mekong Delta: assessment of their potential for monitoring ENSO and East Asian monsoon. Global and Planetary Change 63(4):341-52.

Nydal R. 2000. Radiocarbon in the ocean. Radiocarbon 42(1):81-98.

Petchey F, Phelan M, White JP. 2004. New $\Delta$ R values for the southwest Pacific Ocean. Radiocarbon 46:1005-14

Philippsen B. 2013. The freshwater reservoir effect in radiocarbon dating. Heritage Science 1:24.

Pohlmann T. 1987. A three dimensional circulation model of the South China Sea. In: Nihoul JCJ Jamart BM, editors. Three-Dimensional Models of Marine and Estuarine Dynamics. (Period rather than comma after Dynamics) Elsevier Oceanography Series 45. Amsterdam: Elsevier. p 245-68.

Qu T, Kim YY, Yaremchuk M, Tozuka T, Ishida A, Yamagata T. 2004. Can Luzon Strait transport play a role in conveying the impact of ENSO to the South China Sea? Journal of Climate 17(18):3644-57.

Qu T, Du Y, Sasaki H. 2006. South China Sea throughflow: a heat and freshwater conveyor. Geophysical Research Letters 33:L23617.

Reimer PJ, Bard E, Bayliss A, Beck JW, Blackwell PG, Bronk Ramsey C, Buck CE, Cheng H, Edwards RL, Friedrich M, Grootes PM, Guilderson TP, Haflidason H, Hajdas I, Hatté C, Heaton TJ, Hoffmann DL, Hogg AG, Hughen KA, Kaiser KF, Kromer B, Manning SW, Niu M, Reimer RW, Richards DA, Scott EM, Southon JR, Staff RA, Turney CSM, van der Plicht J. 2013. IntCal13 and Marine13 radiocarbon age calibration curves $0-50,000$ years cal BP. Radiocarbon 55(4):1869-87.

Reynaud-Vaganay S, Gattuso J-P, Cuif J-P, Jaubert J, Juillet-Leclerc A. 1999. A novel culture technique for scleractinian corals: application to investigate changes in skeletal $\delta^{18} \mathrm{O}$ as a function of temperature. Marine Ecology-Progress Series 181:121-32. 
Rhodes EG, Polach HA, Thom BG, Wilson SR. 1980. Age structure of Holocene coastal sediments: Gulf of Carpentaria, Australia. Radiocarbon 22(3):718-27.

Santos RS, Moore MD, Southon JR, Griffin S, Hinger E, Zhang D. 2007. AMS ${ }^{14} \mathrm{C}$ sample preparation at the KCCAMS/UCI facility: status report and performance of small samples. Radiocarbon 49(2):255-69.

Schlitzer R. 2002. Ocean Data View [WWW document]. http://www.awi-bremerhaven.de/GEO/ODV.

Schöne BR, Freyre Castro AD, Fiebig J, Houk SD, Oschmann W, Kröncke I. 2004. Sea surface water temperatures over the period 1884-1983 reconstructed from oxygen isotope ratios of a bivalve mollusk shell (Arctica islandica, southern North Sea). Palaeogeography, Palaeoclimatology, Palaeoecology 212(3-4):215-32.

Schrag DP. 1999. Rapid analysis of high precision $\mathrm{Sr} / \mathrm{Ca}$ ratios in corals and other marine carbonates. Paleoceanography 14(2):97-102.

Shaw PT, Chao SY. 1994. Surface circulation in the South China Sea. Deep-Sea Research I 40(11/12): 1663-83.

Smith SV, Buddemeier RW, Redalje RC, Houck JE. 1979. Strontium-calcium thermometry in coral skeletons. Science 204(4391):404-7.

Southon J, Kashgarian M, Fontugne M, Metivier B, Yim WW-S. 2002. Marine reservoir corrections for the Indian Ocean and Southeast Asia. Radiocarbon 44(1):167-80.

Southon JR, Santos M, Druffel-Rodriguez KC, Druffel ERM, Trumbore SE, Xu SGX, Ali S, Mazon M. 2004. The Keck Carbon Cycle AMS Laboratory, University of California, Irvine: initial operation and a background surprise. Radiocarbon 46(1):41-50.

Stuiver M, Braziunas TF. 1993. Modeling atmospheric ${ }^{14} \mathrm{C}$ influences and radiocarbon ages of marine samples back to 10,000 BC. Radiocarbon 35(1):215-30.

Stuiver M, Polach HA. 1977. Discussion: reporting of ${ }^{14} \mathrm{C}$ data. Radiocarbon 19(3):355-63.

Suess HE. 1953. Natural radiocarbon and the rate of exchange of $\mathrm{CO}_{2}$ between the atmosphere and the sea. In: Proceedings of the Conference on Nuclear Processes in Geological Settings. Chicago: University of Chicago Press. p 52-6.

Swart PK, Leder JJ, Szmant AM, Dodge RE. 1996. The origin of variations in the isotopic record of scleractinian corals: II. Carbon. Geochimica et Cosmochimica Acta 60(15):2871-85.

Wang D, Wang H, Li M, Liu G, Wu X. 2013. Role of Ekman transport versus Ekman pumping in driving summer upwelling in the South China Sea. Journal of Ocean University of China 12(3):355-65.

Wang P, Li PQ, editors. 2009. The South China Sea. Developments in Paleoenvironmental Research 13. Berlin: Springer e-books.

Wu C-R, Shaw P-T, Chao S-Y. 1998. Seasonal and interannual variations in the velocity field of the South China Sea. Journal of Oceanography 54(4):361-72.

Wyrtki K. 1961. Physical Oceanography of the Southeast Asian Waters Scientific Results of Marine Investigations of the South China Sea and the Gulf of Thailand. La Jolla: Scripps Institution of Oceanography. p 1-195.

Xie S-P, Xie Q, Wang D, Liu WT. 2003. Summer upwelling in the South China Sea and its role in regional climate variations. Journal of Geophysical Research: Oceans 108(C8):3261.

Xu XZ, Qiu Z, Chen HC. 1982. The general descriptions of the horizontal circulation in the South China Sea. Symposium on Hydrometerology of the Chinese Society of Oceanology and Limnology and Oceanography. In: Proceedings of the 1980 Symposium on Hydrometerology of the Chinese Society of Oceanology and Limnology. Beijing: Science Press. p 137-45. In Chinese with English abstract.

Xu X, Trumbore S, Zheng S, Southon J, McDuffee K, Luttgen M, Liu J. 2007. Modifying a sealed tube zinc reduction method for preparation of AMS graphite targets: reducing background and attaining high precision. Nuclear Instruments and Methods in Physics Research B 259(1):320-9.

Xue H, Chai F, Pettigrew N, Xu D, Shi M, Xu J. 2004. Kuroshio intrusion and the circulation in the South China Sea. Journal of Geophysical Research: Oceans 109(C2):C02017.

Yoneda M, Uno H, Shibata Y, Suzuki R, Kumamoto Y, Yoshida K, Sasaki T, Suzuki A, Kawahata K. 2007. Radiocarbon marine reservoir ages in the western Pacific estimated by pre-bomb molluscan shells. Nuclear Instruments and Methods in Physics Research B 259(1):432-7.

Zhang N, Lan J, Cui F. 2014. The shallow meridional overturning circulation of the South China Sea. Ocean Science Discussions 11:1191-212. 


\section{APPENDICES}

Appendix 1 Annual pre-bomb $\Delta{ }^{14} \mathrm{C}(1900-1953)$ and calculated marine reservoir age $(\mathrm{R})$ and marine reservoir correction $(\Delta \mathrm{R})$ from Hon Tre Island, Vietnam.

\begin{tabular}{|c|c|c|c|c|c|c|c|c|c|c|c|c|c|c|}
\hline ID & UCID\# & $\begin{array}{l}\text { Year } \\
(A D)\end{array}$ & $\begin{array}{l}\text { Coral } \\
\Delta^{14} \mathrm{C} \\
(\% \circ)\end{array}$ & $\pm 1 \sigma$ & $\begin{array}{l}\text { Coral } \\
{ }^{14} \mathrm{C} \text { age } \\
(\mathrm{BP})\end{array}$ & $\pm 1 \sigma$ & $\begin{array}{l}\text { Atmospheric } \\
\text { modeled } \\
{ }^{14} \mathrm{C} \text { age }(\mathrm{BP})\end{array}$ & $\pm 1 \sigma$ & $\begin{array}{l}\text { Marine } \\
\text { modeled } \\
\Delta^{14} \mathrm{C}(\% \circ)\end{array}$ & $\pm 1 \sigma$ & $\begin{array}{l}\text { Marine } \\
\text { modeled }{ }^{14} \mathrm{C} \\
\text { age }(\mathrm{BP})\end{array}$ & $\pm 1 \sigma$ & $\begin{array}{l}\mathrm{R} \\
(\mathrm{Yr})\end{array}$ & $\begin{array}{l}\Delta \mathrm{R} \\
(\mathrm{Yr})\end{array}$ \\
\hline TN6A-3 & UCID16782 & 1953 & -48.75 & 2.1 & 400 & 20 & & & & & & & & \\
\hline TN6A-4 & UCID16783 & 1952 & -60.83 & 2.0 & 500 & 20 & & & & & & & & \\
\hline TN6A-5 & UCID16784 & 1951 & -56.31 & 2.2 & 465 & 20 & & & & & & & & \\
\hline TN6A-6 & UCID16785 & 1950 & -55.7 & 2.2 & 460 & 20 & 199 & 8 & -56.7 & 2.7 & 469 & 23 & 261 & -9 \\
\hline TN6A-7 & UCID16786 & 1949 & -60.5 & 2.2 & 500 & 20 & 188 & 8 & -55.6 & 2.7 & 464 & 23 & 312 & 36 \\
\hline TN6A-8 & UCID16787 & 1948 & -58.6 & 2.3 & 485 & 20 & 188 & 8 & -55.6 & 2.7 & 464 & 23 & 297 & 21 \\
\hline $\begin{array}{l}\text { TN6A-8 } \\
\text { (Duplicate) }\end{array}$ & UCID16832 & 1948 & -60.8 & 2.2 & 505 & 20 & 188 & 8 & -55.6 & 2.7 & 464 & 23 & 317 & 41 \\
\hline TN6A-9 & UCID16788 & 1947 & -60.5 & 2.4 & 505 & 25 & 188 & 8 & -55.6 & 2.7 & 464 & 23 & 317 & 41 \\
\hline TN6A-10 & UCID16789 & 1946 & -58.3 & 2.2 & 485 & 20 & 188 & 8 & -55.6 & 2.7 & 464 & 23 & 297 & 21 \\
\hline TN6A-11 & & 1945 & & & & & 188 & 8 & -55.6 & 2.7 & 464 & 23 & & \\
\hline TN6B-1 & UCID18314 & 1944 & -57.7 & 2.0 & 485 & 20 & 172 & 8 & -54.5 & 2.7 & 460 & 23 & 313 & 25 \\
\hline TN6B-2 & & 1943 & & & & & 172 & 8 & -54.5 & 2.7 & 460 & 23 & & \\
\hline TN7-01 & UCID16790 & 1945 & -56.4 & 2.3 & 470 & 20 & 188 & 8 & -54.5 & 2.7 & 464 & 23 & 282 & 6 \\
\hline TN7-02 & UCID16791 & 1944 & -56.3 & 2.2 & 470 & 20 & 172 & 8 & -54.5 & 2.7 & 460 & 23 & 298 & 10 \\
\hline TN7-03 & UCID16792 & 1943 & -54.1 & 2.2 & 455 & 20 & 172 & 8 & -54.5 & 2.7 & 460 & 23 & 283 & -5 \\
\hline TN7-04 & UCID16793 & 1942 & -53.6 & 2.2 & 450 & 20 & 172 & 8 & -54.5 & 2.7 & 460 & 23 & 278 & -10 \\
\hline TN7-05 & UCID16794 & 1941 & -58.7 & 2.0 & 495 & 20 & 172 & 8 & -54.5 & 2.7 & 460 & 23 & 323 & 35 \\
\hline TN7-06 & UCID16795 & 1940 & -55.6 & 2.2 & 470 & 20 & 172 & 8 & -54.5 & 2.7 & 460 & 23 & 298 & 10 \\
\hline TN7-07 & UCID16796 & 1939 & -57.7 & 2.1 & 490 & 20 & 154 & 8 & -54.5 & 2.7 & 457 & 23 & 336 & 33 \\
\hline $\begin{array}{l}\text { TN7-07 } \\
\text { (Duplicate) }\end{array}$ & UCID16833 & 1939 & -57.7 & 1.8 & 487 & 20 & 154 & 8 & -53.6 & 2.7 & 457 & 23 & 333 & 30 \\
\hline TN7-08 & UCID16797 & 1938 & -57.7 & 2.1 & 490 & 20 & 154 & 8 & -53.6 & 2.7 & 457 & 23 & 336 & 33 \\
\hline TN7-09 & UCID16798 & 1937 & -53.8 & 2.2 & 455 & 20 & 154 & 8 & -53.6 & 2.7 & 457 & 23 & 301 & -2 \\
\hline TN7-10 & UCID16799 & 1936 & -57.2 & 2.3 & 485 & 20 & 154 & 8 & -53.6 & 2.7 & 457 & 23 & 331 & 28 \\
\hline TN7-11 & UCID16800 & 1935 & -56.5 & 2.1 & 480 & 20 & 154 & 8 & -53.6 & 2.7 & 457 & 23 & 326 & 23 \\
\hline
\end{tabular}




\begin{tabular}{|c|c|c|c|c|c|c|c|c|c|c|c|c|c|c|}
\hline TN7-12 & UCID16801 & 1934 & -56.6 & 2.2 & 485 & 20 & 152 & 8 & -53.6 & 2.7 & 454 & 23 & 333 & 31 \\
\hline TN7-13 & UCID16802 & 1933 & -54.4 & 2.3 & 465 & 20 & 152 & 8 & -52.7 & 2.7 & 454 & 23 & 313 & 11 \\
\hline TN7-14 & UCID16803 & 1932 & -53.5 & 2.2 & 460 & 20 & 152 & 8 & -52.7 & 2.7 & 454 & 23 & 308 & 6 \\
\hline TN7-15 & UCID16804 & 1931 & -52.3 & 2.2 & 450 & 20 & 152 & 8 & -52.7 & 2.7 & 454 & 23 & 298 & -4 \\
\hline TN7-16 & UCID16805 & 1930 & -55.4 & 2.2 & 480 & 20 & 152 & 7 & -52.7 & 2.7 & 454 & 23 & 328 & 26 \\
\hline TN7-17 & UCID16806 & 1929 & -54.1 & 2.2 & 465 & 20 & 132 & 7 & -52.7 & 2.7 & 451 & 23 & 333 & 14 \\
\hline TN7-18 & UCID16807 & 1928 & -53.4 & 2.2 & 460 & 20 & 132 & 7 & -51.7 & 2.7 & 451 & 23 & 328 & 9 \\
\hline TN7-19 & UCID16808 & 1927 & -51.4 & 1.6 & 445 & 15 & 132 & 7 & -51.7 & 2.7 & 451 & 23 & 313 & -6 \\
\hline TN7-19 & UCID16884 & 1927 & -54.1 & 1.2 & 470 & 15 & 132 & 7 & -51.7 & 2.7 & 451 & 23 & 338 & 19 \\
\hline $\begin{array}{l}\text { TN7-19 } \\
\text { (Triplicate) }\end{array}$ & UCID17254 & 1927 & -52.9 & 1.6 & 460 & 15 & 132 & 7 & -51.7 & 2.7 & 451 & 23 & 328 & 9 \\
\hline TN7-20 & UCID16809 & 1926 & -52.9 & 1.6 & 460 & 15 & 132 & 7 & -51.7 & 2.7 & 451 & 23 & 328 & 9 \\
\hline TN7-21 & UCID16810 & 1925 & -52.5 & 1.6 & 460 & 15 & 132 & 6 & -51.7 & 2.7 & 451 & 23 & 328 & 9 \\
\hline TN7-22 & UCID16811 & 1924 & -54.0 & 1.5 & 470 & 15 & 129 & 6 & -51.7 & 2.7 & 449 & 23 & 341 & 21 \\
\hline TN7-23 & & 1923 & & & & & 129 & 6 & -50.9 & 2.7 & 449 & 23 & & \\
\hline TN7-24 & UCID16813 & 1922 & -53.1 & 1.5 & 465 & 15 & 129 & 6 & -50.9 & 2.7 & 449 & 23 & 336 & 16 \\
\hline TN7-25 & UCID16814 & 1921 & -53.3 & 1.6 & 470 & 15 & 129 & 6 & -50.9 & 2.7 & 449 & 23 & 341 & 21 \\
\hline TN7-26 & UCID16815 & 1920 & -52.1 & 1.7 & 460 & 15 & 129 & 7 & -50.9 & 2.7 & 449 & 23 & 331 & 11 \\
\hline TN7-27 & UCID16816 & 1919 & -53.8 & 1.6 & 475 & 15 & 104 & 7 & -50.9 & 2.7 & 449 & 23 & 371 & 26 \\
\hline TN7-28 & UCID16817 & 1918 & -51.3 & 1.6 & 455 & 15 & 104 & 7 & -50.2 & 2.7 & 448 & 23 & 351 & 7 \\
\hline TN7-29 & UCID16818 & 1917 & -49.9 & 1.6 & 445 & 15 & 104 & 7 & -50.2 & 2.7 & 448 & 23 & 341 & -3 \\
\hline TN7-30 & UCID16819 & 1916 & -52.0 & 1.5 & 460 & 15 & 104 & 7 & -50.2 & 2.7 & 448 & 23 & 356 & 12 \\
\hline TN7-31 & UCID 16820 & 1915 & -53.0 & 1.6 & 470 & 15 & 104 & 7 & -50.2 & 2.7 & 448 & 23 & 366 & 22 \\
\hline TN7-32 & UCID16821 & 1914 & -53.8 & 1.5 & 480 & 15 & 99 & 7 & -50.2 & 2.7 & 448 & 23 & 381 & 32 \\
\hline $\begin{array}{l}\text { TN7-32 } \\
\text { (Duplicate) }\end{array}$ & UCID16834 & 1914 & -54.3 & 1.5 & 485 & 15 & 99 & 7 & -49.7 & 2.7 & 448 & 23 & 386 & 37 \\
\hline TN7-33 & UCID16822 & 1913 & -52.7 & 1.5 & 470 & 15 & 99 & 7 & -49.7 & 2.7 & 448 & 23 & 371 & 22 \\
\hline TN7-34 & UCID16823 & 1912 & -52.8 & 1.6 & 470 & 15 & 99 & 7 & -49.7 & 2.7 & 448 & 23 & 371 & 22 \\
\hline TN7-35 & UCID16824 & 1911 & -53.1 & 1.5 & 475 & 15 & 99 & 7 & -49.7 & 2.7 & 448 & 23 & 376 & 27 \\
\hline TN7-36 & UCID16825 & 1910 & -53.5 & 1.6 & 480 & 15 & 99 & 7 & -49.7 & 2.7 & 448 & 23 & 381 & 32 \\
\hline TN7-37 & UCID16826 & 1909 & -53.2 & 1.6 & 480 & 15 & 84 & 7 & -49.7 & 2.7 & 449 & 23 & 396 & 31 \\
\hline TN7-38 & UCID16827 & 1908 & -54.2 & 1.5 & 490 & 15 & 84 & 7 & -49.2 & 2.7 & 449 & 23 & 406 & 41 \\
\hline TN7-39 & UCID16828 & 1907 & -51.9 & 1.5 & 470 & 15 & 84 & 7 & -49.2 & 2.7 & 449 & 23 & 386 & 21 \\
\hline TN7-40 & UCID16829 & 1906 & -49.6 & 1.6 & 450 & 15 & 84 & 7 & -49.2 & 2.7 & 449 & 23 & 366 & 1 \\
\hline
\end{tabular}


Appendix 1 (Continued)

\begin{tabular}{|c|c|c|c|c|c|c|c|c|c|c|c|c|c|c|}
\hline ID & UCID\# & $\begin{array}{l}\text { Year } \\
\text { (AD) }\end{array}$ & $\begin{array}{l}\text { Coral } \\
\Delta^{14} \mathrm{C} \\
(\% \circ)\end{array}$ & $\pm 1 \sigma$ & $\begin{array}{l}\text { Coral } \\
{ }^{14} \mathrm{C} \text { age } \\
(\mathrm{BP})\end{array}$ & $\pm 1 \sigma$ & $\begin{array}{l}\text { Atmospheric } \\
\text { modeled } \\
{ }^{14} \mathrm{C} \text { age }(\mathrm{BP})\end{array}$ & $\pm 1 \sigma$ & $\begin{array}{l}\text { Marine } \\
\text { modeled } \\
\Delta{ }^{14} \mathrm{C}(\% \circ)\end{array}$ & $\pm 1 \sigma$ & $\begin{array}{l}\text { Marine } \\
\text { modeled }{ }^{14} \mathrm{C} \\
\text { age (BP) }\end{array}$ & $\pm 1 \sigma$ & $\begin{array}{l}\mathrm{R} \\
(\mathrm{Yr})\end{array}$ & $\begin{array}{l}\Delta \mathrm{R} \\
(\mathrm{Yr})\end{array}$ \\
\hline TN7-41 & UCID16830 & 1905 & -52.7 & 1.7 & 480 & 15 & 84 & 7 & -49.2 & 2.7 & 449 & 23 & 396 & 31 \\
\hline TN7-42 & UCID16831 & 1904 & -51.1 & 1.6 & 465 & 15 & 70 & 7 & -49.2 & 2.7 & 454 & 23 & 395 & 11 \\
\hline $\begin{array}{l}\text { TN7-42 } \\
\text { (Duplicate) }\end{array}$ & UCID16835 & 1904 & -52.8 & 1.5 & 481 & 15 & 70 & 7 & -49.2 & 2.7 & 454 & 23 & 411 & 27 \\
\hline TN8-1 & UCID16841 & 1903 & -51.1 & 1.3 & 465 & 15 & 70 & 7 & -49.2 & 2.7 & 454 & 23 & 395 & 11 \\
\hline TN8-2 & UCID16842 & 1902 & -51.2 & 1.2 & 470 & 15 & 70 & 7 & -49.2 & 2.7 & 454 & 23 & 400 & 16 \\
\hline TN8-3 & UCID16843 & 1901 & -51.7 & 1.2 & 475 & 15 & 70 & 7 & -49.2 & 2.7 & 454 & 23 & 405 & 21 \\
\hline TN8-4 & UCID16844 & 1900 & -52.4 & 1.3 & 480 & 15 & 70 & 7 & -49.2 & 2.7 & 454 & 23 & 410 & 26 \\
\hline
\end{tabular}


Appendix 2 Annual post-bomb $\Delta{ }^{14} \mathrm{C}(1954-1986)$ and seasonal (1969) $\Delta{ }^{14} \mathrm{C}$ and $\mathrm{Sr} / \mathrm{Ca}$ ratios, Hon Tre Island, Vietnam.

\begin{tabular}{|c|c|c|c|c|c|c|c|}
\hline ID & UCID\# & $\begin{array}{l}\text { Year } \\
\text { (AD) }\end{array}$ & $\begin{array}{l}\text { Coral } \\
\Delta \Delta^{14} \mathrm{C}(\% \circ)\end{array}$ & $\begin{array}{l} \pm 1 \sigma \\
(\%)\end{array}$ & $\begin{array}{l}\text { Coral }{ }^{14} \mathrm{C} \\
\text { age (BP) }\end{array}$ & $\begin{array}{l} \pm 1 \sigma \\
(\mathrm{BP})\end{array}$ & $\begin{array}{l}\mathrm{Sr} / \mathrm{Ca} \\
(\mathrm{mmol} / \\
\mathrm{mol})\end{array}$ \\
\hline TN3-11 & UCID18644 & 1986 & 123.8 & 2.8 & & & \\
\hline TN3-13 & UCID18663 & 1984 & 140 & 2.9 & & & \\
\hline TN3-14 & UCID18632 & 1983 & 139.54 & 2.9 & & & \\
\hline TN4-1 & UCID18633 & 1982 & 136.19 & 2.9 & & & \\
\hline TN4-2 & UCID18634 & 1981 & 142.81 & 2.9 & & & \\
\hline TN4-2 dup of 18634 & UCID18668 & 1981 & 140.02 & 2.9 & & & \\
\hline TN4-3 & UCID18635 & 1980 & 143.34 & 2.9 & & & \\
\hline TN4-5 & UCID18636 & 1978 & 151.49 & 2.9 & & & \\
\hline TN4-7 OS & UCID18914 & 1974 & 141.58 & 2.4 & & & \\
\hline TN4-9 OS & UCID18915 & 1972 & 146.94 & 2.5 & & & \\
\hline TN4-10 & UCID18637 & 1973 & 155.28 & 2.9 & & & \\
\hline TN4-12 OS & UCID18916 & 1970 & 147.12 & 2.3 & & & \\
\hline TN4-14.7 & UCID19189 & 1969.91 & 150.92 & 1.7 & & & 9.059 \\
\hline TN4-14.6 & UCID19188 & 1969.78 & 153.64 & 1.7 & & & 9.195 \\
\hline TN4-14.5 & UCID19187 & 1969.65 & 156.35 & 1.7 & & & 9.093 \\
\hline TN4-14.4 & UCID19186 & 1969.52 & 156.47 & 1.7 & & & 9.004 \\
\hline TN4-14.3 & UCID19185 & 1969.39 & 142.22 & 1.9 & & & 8.879 \\
\hline TN4-14.2 & UCID19184 & 1969.26 & 138.44 & 1.7 & & & 8.896 \\
\hline TN4-14.1 & UCID19183 & 1969 & 151.95 & 1.7 & & & 8.861 \\
\hline TN4-15 & UCID18638 & 1968 & 144.9 & 2.9 & & & \\
\hline TN4-16 & UCID18639 & 1967 & 142.05 & 2.9 & & & \\
\hline TN4-17 & UCID18640 & 1966 & 136.6 & 2.9 & & & \\
\hline TN4-18 & UCID18641 & 1965 & 136.47 & 2.9 & & & \\
\hline TN4-19 & UCID18642 & 1964 & 128.09 & 2.9 & & & \\
\hline TN5-1 & UCID17052 & 1963.8 & 111.14 & 2.1 & & & \\
\hline TN5-2 & UCID17053 & 1963 & 74.51 & 1.8 & & & \\
\hline TN5-3 & UCID17054 & 1962 & 37.59 & 2.1 & & & \\
\hline TN5-4 & UCID17055 & 1961 & 8.26 & 1.9 & & & \\
\hline TN5-5 & UCID17056 & 1960 & -2.41 & 1.8 & 10 & 15 & \\
\hline TN5-6 & UCID17057 & 1959 & -4.28 & 1.6 & 25 & 15 & \\
\hline TN5-7 & UCID17058 & 1958 & -18.45 & 1.7 & 140 & 15 & \\
\hline TN5-7 (Duplicate) & UCID17059 & 1958 & -15.65 & 1.8 & 120 & 15 & \\
\hline TN5-8 & UCID17060 & 1957 & -31.92 & 1.5 & 255 & 15 & \\
\hline TN6A-1 & UCID16780 & 1955 & -36.58 & 2.1 & 295 & 20 & \\
\hline TN6A-2 & UCID16781 & 1954 & -43.56 & 2.3 & 355 & 20 & \\
\hline
\end{tabular}


Appendix 3 Compilation of ${ }^{14} \mathrm{C}$ ages from marine carbonates samples from the SCS and surrounding regions. Data obtained from the Marine Reservoir Correction database (see http://calib.qub.ac.uk/marine/).

\begin{tabular}{|c|c|c|c|c|c|c|c|c|c|c|c|c|}
\hline $\begin{array}{l}\text { Symbols as per } \\
\text { Figures } 1 \text { to } 3 \text {, } \\
\text { Letters as per } \\
\text { Figure } 1\end{array}$ & Reference & Sample type & $\begin{array}{l}\text { Year } \\
\text { (AD) }\end{array}$ & Location & $\begin{array}{l}\text { Lat } \\
\left({ }^{\circ} \mathrm{N}\right)\end{array}$ & $\begin{array}{l}\text { Long } \\
\left({ }^{\circ} \mathrm{E}\right)\end{array}$ & $\begin{array}{l}{ }^{14} \mathrm{C} \\
\text { age } \\
\text { (yr) }\end{array}$ & $\begin{array}{l}{ }^{14} \mathrm{C} \text { age } \\
\text { error } \\
(\mathrm{yr})\end{array}$ & $\begin{array}{l}\text { Reservoir } \\
\text { age (yr) }\end{array}$ & $\begin{array}{l}\text { Reservoir } \\
\text { age error } \\
(\mathrm{yr})\end{array}$ & $\begin{array}{l}\Delta \mathrm{R} \\
(\mathrm{yr})\end{array}$ & $\begin{array}{l}\Delta \mathrm{R} \\
\text { error } \\
(\mathrm{yr})\end{array}$ \\
\hline Blue circle & Dang et al. 2004 & $\begin{array}{l}\text { Coral (Porites } \\
\text { spp.) }\end{array}$ & 1952 & $\begin{array}{l}\text { Con Dao Island, } \\
\text { Vietnam }\end{array}$ & 8.7 & 106.5 & 398 & 30 & 190 & 35 & -70 & 30 \\
\hline Red square & This study & Coral (P. lutea) & 1950 & $\begin{array}{l}\text { Hon Tre Island, } \\
\text { Vietnam }\end{array}$ & 12.2 & 109.2 & 465 & 20 & 266 & 22 & -4 & 30 \\
\hline Purple diamond & $\begin{array}{l}\text { Fallon and } \\
\text { Guilerson } 2008\end{array}$ & Coral (P. lutea) & 1950 & $\begin{array}{l}\text { Langkai Island, } \\
\text { Indonesia }\end{array}$ & 5.0 & 119.0 & 473 & 27 & 274 & 28 & 4 & 35 \\
\hline A & Southon et al. 2002 & Bivalve & 1945 & Singapore & 2.9 & 103.8 & 448 & 38 & 260 & 39 & -15 & 38 \\
\hline B & Southon et al. 2002 & Bivalve & 1945 & Saigon, Vietnam & 10.8 & 106.8 & 440 & 56 & 252 & 57 & -23 & 56 \\
\hline $\mathrm{C}$ & Goodkin et al. 2011 & Coral (P. lutea) & 1942 & Hong Kong & 22.2 & 114.1 & 570 & 20 & 392 & 22 & 110 & 31 \\
\hline Green triangle & Dutta et al. 2001 & Bivalve & 1935 & Andaman Sea & 13.0 & 92.6 & 469 & 34 & 458 & 4 & 11 & 35 \\
\hline $\mathrm{D}$ & $\begin{array}{l}\text { Hideshima et al. } \\
2001\end{array}$ & Coral (P. lutea) & 1931 & Ishigaki, Japan & 24.6 & 124.3 & 470 & 40 & 318 & 40 & 15 & 40 \\
\hline $\mathrm{E}$ & Athens 1986 & Gastropod & 1930 & Guam & 13.4 & 144.7 & 590 & 50 & 438 & 51 & 136 & 50 \\
\hline Orange triangle & Konishi et al. 1982 & Coral (P. lutea $)$ & 1927 & Okinanwa, Japan & 26.4 & 127.8 & 326 & 7 & 186 & 10 & -126 & 7 \\
\hline $\mathrm{F}$ & Southon et al. 2002 & Gastropod & 1925 & $\begin{array}{l}\text { South Borneo, } \\
\text { Indonesia }\end{array}$ & -3.0 & 111.5 & 540 & 70 & 391 & 71 & 89 & 70 \\
\hline G & Petchey et al. 2004 & Gastropod & 1919 & $\begin{array}{l}\text { New Ireland, Papua } \\
\text { New Guinea }\end{array}$ & -2.6 & 150.8 & 760 & 60 & 629 & 61 & 311 & 60 \\
\hline $\mathrm{H}$ & Southon et al. 2002 & Gastropod & 1916 & $\begin{array}{l}\text { Mona Islands, } \\
\text { Philippines }\end{array}$ & 12.0 & 120.0 & 410 & 70 & 301 & 70 & -37 & 70 \\
\hline I & Southon et al. 2002 & Gastropod & 1916 & $\begin{array}{l}\text { Luzon Strait, } \\
\text { Philippines }\end{array}$ & 13.8 & 120.9 & 390 & 50 & 281 & 50 & -57 & 50 \\
\hline $\mathrm{J}$ & Southon et al. 2002 & Gastropod & 1910 & Java, Indonesia & -7.0 & 106.5 & 490 & 70 & 362 & 71 & 42 & 70 \\
\hline $\mathrm{K}$ & Southon et al. 2002 & Gastropod & 1908 & $\begin{array}{l}\text { Mindoro Strait, } \\
\text { Philippines }\end{array}$ & 12.5 & 120.5 & 540 & 70 & 447 & 70 & 92 & 70 \\
\hline $\mathrm{L}$ & Southon et al. 2002 & Coral (P. lutea) & 1906 & Paracel Islands & 16.7 & 112.3 & 460 & 40 & 375 & 41 & 11 & 40 \\
\hline M & Petchey et al. 2004 & Gastropod & 1905 & $\begin{array}{l}\text { St. Georges Channel, } \\
\text { Papua New Guinea }\end{array}$ & -4.2 & 152.4 & 492 & 68 & 372 & 68 & 43 & 68 \\
\hline
\end{tabular}


1903 Guam

$\begin{array}{llll}13.5 & 144.8 & 470 & 50\end{array}$

1903 Gulf of Carpentaria, -12.0 $141.0 \quad 436 \quad 60$ Australia

Yoneda et al. 2007 Gastropod

Yoneda et al. 2007 Gastropod

Southon et al. 2002 Gastropod

Gillespie and

Bivalve

Polach 1979

1896 Suao, Taiwan

$\begin{array}{llll}24.0 & 121.5 & 443 & 59\end{array}$

$24.0 \quad 121.5 \quad 559 \quad 43$

1884 Bonin Island, Japan $27.0 \quad 142.0 \quad 300 \quad 60$

1875 Torres Strait, $\quad-10.0 \quad 143.0 \quad 553 \quad 85$ Australia

Southon et al. 2002 Bivalve

Southon et al. 2002 Bivalve

$\begin{array}{llll}1.3 & 103.9 & 360 & 60\end{array}$

$\begin{array}{rrrr}-11.3 & 132.4 & 549 \quad 40\end{array}$

1841 Raffles Bay,

Australia 